\title{
Environmental impact of heavy metal concentration in the Coatzacoalcos River, Veracruz, Mexico.
}

Glicinia Valentina Ortiz-Zamora ${ }^{1}$, Mardocheo Palma ${ }^{2}$, Juan José Kasper-Zubillaga ${ }^{3}$, David Alberto Salas de León ${ }^{3}$, María Adela Monreal-Gómez ${ }^{3}$ and Zoila CastilloRodriguez $^{3}$.

${ }^{1}$ Laboratorio de Paleomagnetismo y Geofísica Nuclear, Instituto de Geofísica, UNAM, Ciudad Universitaria, Coyoacán, C.P. 04510, México D.F., México.

${ }^{2}$ Laboratorio de Geoecología, Centro de Investigaciones en Ecosistemas, UNAM Campus Morelia, México. * mfpm@hp.fciencias.unam.mx

${ }^{3}$ Instituto de Ciencias del Mar y Limnología, UNAM, Ciudad Universitaria, Coyoacán, C.P. 04510, México D.F., México

\section{ABSTRACT}

A quantitative environmental impact study on heavy metal concentration $(\mathrm{Cr}, \mathrm{Cu}, \mathrm{Mn}, \mathrm{Cd}, \mathrm{Pb}$, $\mathrm{Co}$ and $\mathrm{Ni}$ ) in the water, sediments and benthic fauna of the Coatzacoalcos River, Mexico was carried out to establish relationships between heavy metal concentration and human activity (urban and agricultural activities). The Coatzacoalcos River is characterized by one of the largest estuarine systems in the eastern coast of Mexico, and exhibits a large diversity of mangroves, palm trees and terrestrial invertebrates. However, the river has suffered from impacts of petrochemical activities in the past. Sediments, water and benthic fauna were collected during four sampling periods in September 1996 (rainy season), January 1997 (dry season), April 1997 (dry season) and August 1997 (rainy season). Dry sieving of the sediments was carried out. Also in situ measurements of organic matter content and heavy metal concentration were determined for seventeen river stations. The first and fourth samplings showed that most sediment in the Coatzacoalcos River is transported by suspension during the rainy season. The second and third sampling showed saltation as the main mode of transport during the dry season. Nine stations in the river were environmentally impacted by industrial and urban discharges leading to high $\mathrm{Cu}$ and $\mathrm{Cr}$ concentration values in water and sediments. Poor recovery of benthic organisms was observed for most Coatzacoalcos River stations. Depletion of benthic organisms was due to intensive dredging activity in the past decades as well as low $\mathrm{O}_{2}$ values in the water column. Bivalves, Rangia concentrate 1.1 times more $\mathrm{Cu}$ than $\mathrm{Cr}$ than others Polimesoda from sediments. Polimesoda carolineana, Rangia cuneata and Rangia flexuosa concentrate 2.2 times more $\mathrm{Cr}$ than $\mathrm{Cu}$ from water. Rangia also concentrates 4.2 times more $\mathrm{Cu}$ than $\mathrm{Cr}$ in sediments. This suggests that the three species have an efficient excretory system to tolerate and eliminate the excess of $\mathrm{Cu}$. A varimax rotated factor analysis showed that the highest impacted stations of the Coatzacoalcos River area 
influenced by the lack of turbidness and depletion of $\mathrm{O}_{2}$ with high water temperatures related to industrial discharges and high $\mathrm{Cu}$ and $\mathrm{Cr}$ values in sediments and water.

Key words: heavy metals, water, sediments, benthic fauna, Coatzacoalcos River

\section{RESUMO}

Realizou-se um estudo ambiental quantitativo das concentrações de metais pesados $(\mathrm{Cr}, \mathrm{Cu}$, $\mathrm{Mn}, \mathrm{Cd}, \mathrm{Pb}, \mathrm{Co}$ e $\mathrm{Ni}$ ) na água, sedimentos e fauna do benthos do Rio Coatzacoalcos, bem como uma relação entre as concentrações dos mesmos metais pesados, aliados as respectivas atividades humanas (petroquímica, urbana e agricultura). O Rio Coatzacoalcos possui um dos maiores sistemas estuarinos da costa oriental no Mexico, junto a uma grande diversidade de mangues, palmeiras e animais invertebrados terrestres. As amostragens de sedimentos, água e fauna benthônica foram realizadas durante quatro periodos de coleta entre setembro 1996 (período de chuvas)a janeiro 1997, abril 1997 (período de secas) a agosto de 1997 (período de chuvas). Logo em seguida, os sedimentos foram coletados, e logo em seguida fizeram-se medições "in situ" de conteúdo de matéria orgânica e concentração de metais pesados ao longo de dezessete estações no rio. A primeira e quarta amostragem mostraram que a maioria dos sedimentos no rio Coatzacoalcos foram transportados em suspensão durante a temporada de chuvas. Na segunda e terceira amostragem apontou-se que a saltação era a forma principal de transporte durante a temporada de seca. Nove estações no rio foram impactadas ambientalmente pelas descargas industriais e urbanas, elevando as concentrações de $\mathrm{Cu}$ e $\mathrm{Cr}$ na água e nos sedimentos. A pobre amostragem de fauna do rio se deve a excessiva dragagem efetuada ao longo de décadas, assim como a baixa concentração dos valores de $\mathrm{O}_{2}$ na coluna de água. Os bivalvos: Rangia concentrou 1.1 vezes mais $\mathrm{Cu}$ que $\mathrm{Cr}$ que outros bivalvos como Polimesoda dos sedimentos. Polimesoda carolineana, Rangia cuneata e Rangia flexuosa, concentrou 2.2 vezes mais $\mathrm{Cr}$ que $\mathrm{Cu}$ da água. A Rangia também apresentou uma concentração 4.2 vezes maior que $\mathrm{Cu}$ e $\mathrm{Cr}$ nos sedimentos. Isto sugere que as trés espécies possuem um sistema excretor eficiente que tolera e elimina o exceso de $\mathrm{Cu}$. A análise de fator rotatório "varimax" demonstrou que as estações mais impactadas do Rio Coatzacoalcos são influenciadas pela falta de turbidez e a baixa de $\mathrm{O}_{2}$ com as altas temperaturas que tem relação com as descargas industriais, bem como aos altos valores de $\mathrm{Cu}$ e $\mathrm{Cr}$ nos sedimentos e na água.

Palavras chave: metais pesados, água, sedimentos, fauna benthônica, Rio Coatzacoalcos. 


\section{INTRODUCTION}

Fluvial and coastal resources are in serious risk due to human settlement increase and uncontrollability of agricultural and industrial activities partly cause by the excessive discharge input of heavy minerals in water and soil systems.

Some heavy metals like chrome $(\mathrm{Cr})$, copper $(\mathrm{Cu})$, iron $(\mathrm{Fe})$ and manganese $(\mathrm{Mn})$ are essential in living organisms but potentially hazardous in high concentrations. Others like lead $(\mathrm{Pb})$, cadmium $(\mathrm{Cd})$ and mercury $(\mathrm{Hg})$ are highly toxic in low concentrations (ESPINA AND VANEGAS, 1996). Heavy metals concentrate in water, sediments and organisms throughout geological processes like weathering and volcanism. However, high concentrations of heavy metals are due to petrochemical, agricultural and metallurgical activity and lixiviation of solid residues in the water and sediments (FÖRSTNER AND WITTMANN, 1979).

The Coatzacoalcos River in the southeastern coast of Mexico has become a highly environmentally impacted river due to the petrochemical and agricultural activities in the past two decades (FIGUEROA, 1986; BOTELLO AND PAÉZ, 1986; GALLEGOS, 1986).

The river is characterized by one of the largest estuarine systems in the eastern coast of Mexico which groups a high diversity of mangroves, palm trees and marine and terrestrial invertebrates. Therefore, it is of our major concern to present a study of the environmental impact of human activity in the upper and lower reaches of the Coatzacoalcos River. The aims of this paper are to study the heavy metal concentration $(\mathrm{Cr}, \mathrm{Cu}, \mathrm{Mn}, \mathrm{Cd}, \mathrm{Pb}, \mathrm{Co}$ and $\mathrm{Ni})$ in the water, sediments and benthic fauna of the river and to establish their relationships with the human activity.

\section{STUDY AREA}

The Coatzacoalcos River is located in the state of Veracruz, Mexico at $17^{\circ} 46^{\prime}, 18^{0} 10^{\prime}$ $\mathrm{N}$ latitude and $94^{\circ} 25^{\prime}, 94^{\circ} 31^{\prime} \mathrm{W}$ longitude (Fig. 1). The river basin has 26, $691 \mathrm{Km}^{2}$ with several converging tributaries. Using data from the Mexican Comisión Nacional del Agua, the combined volume of the measured Coatzacoalcos River runoff has been estimated in nearly $15 \times 10^{9} \mathrm{~m}^{3}$ year ${ }^{-1}$, although in an annual sampling cycle important variations have been detected of 1,251 $\mathrm{m}^{3} \mathrm{~s}^{-1}$ in September, $294 \mathrm{~m}^{3} \mathrm{~s}^{-1}$ in January, $129 \mathrm{~m}^{3} \mathrm{~s}^{-1}$ in April and $968 \mathrm{~m}^{3} \mathrm{~s}^{-1}$ in August (ORTIZ et al. 2002). The average evaporation rate in the river is $522 \mathrm{~mm}$. The highest evaporation rate is $2510 \mathrm{~mm}$ (october) (GARCÍA, 1988). 

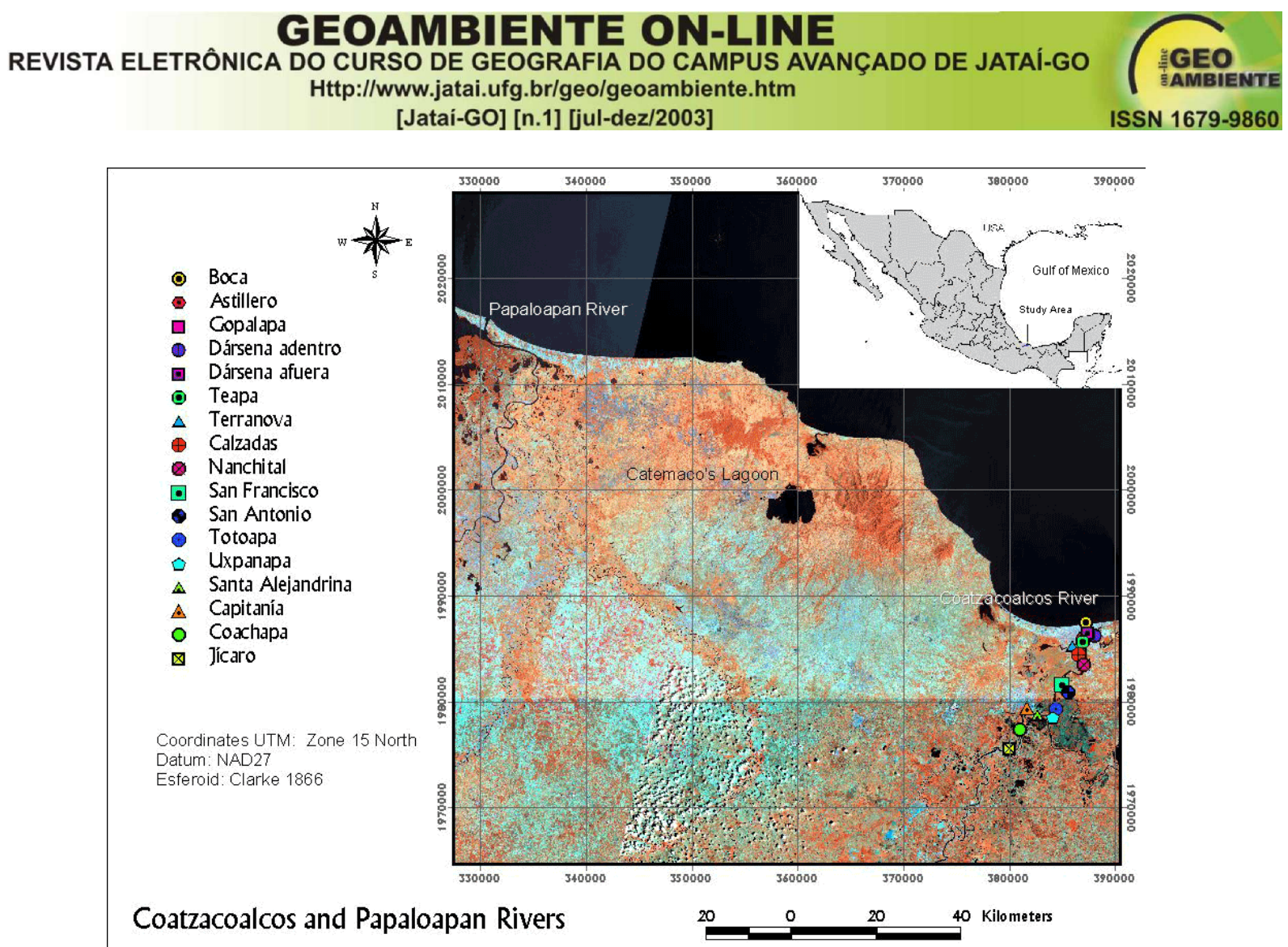

Fig 1. Study area and sampling sites.

The climate in the area is humid with average temperatures of $25.5^{\circ} \mathrm{C}$ in spring and summer. In winter the average temperature is $22.2^{0} \mathrm{C}$. Northeastern and northwestern winds with average velocities of 3.2 to $5.5 \mathrm{~m} / \mathrm{s}$ are dominant in may, august and december respectively (García, 1996). Hurricanes are common in summer and fall. The river is surrounded by a low relief of small hills and flat terrains composed of Miocene sedimentary rocks and Quaternary alluvial deposits (INEGI, 1980a)

\section{EQUIPMENT AND METHODS}

Field work

Sediments, water and benthic fauna were collected during september 1996 (rainy season, first sampling), january 1997 (dry season, second sampling), april 1997 (dry season, third sampling) and august 1997 (rainy season, fourth sampling) in boats using a 1 lt. capacity sedimentary dredge and polyethylene flasks to collect water. Fourteen, sixteen and seventeen sampling stations were considered during the first, second, third and fourth field sampling respectively. A Trimble GPS and topographic charts 1:50 000 (E15-A85) of the INEGI (1980b) were used for sample site positioning.

In situ physical parameters measurements were carried out (Table 1) using a Hidrolab YSI Model 3800 portable field equipment. Sediment subsampling (300 g) was done 
transferring the samples into plastic bags with $\mathrm{HNO}_{3}$ for 72 hours to avoid contamination. Water samples were stored at $40^{\circ} \mathrm{C}$ in flasks adding $\mathrm{HNO}_{3}$ for preservation. Benthic organisms were collected from 2 to 10 lt of sediment and preserved in plastic bags.

Table 1. In situ physical parameters of the Coatzacoalcos River during one annual cycle (1996-1997)

\begin{tabular}{|c|c|c|c|c|c|c|c|c|}
\hline Station & $\mathrm{pH}$ & $T$ & $\mathrm{O}_{2}$ & S o/oo & Eh & Turbidness & $\mathrm{Cu}$ & $\mathrm{Cr}$ \\
\hline Boca sep 96 & 8.19 & 28.3 & ND & 24.8 & 143 & 49 & $\mathrm{ND}$ & $\mathrm{ND}$ \\
\hline \begin{tabular}{|l|} 
Astillero sep 96 \\
\end{tabular} & 7349 & 26.4 & ND & 0.10 & 234 & 75 & ND & $\mathrm{ND}$ \\
\hline Gopalapa sep 96 & 7.59 & 26.4 & ND & 0.10 & 238 & 342 & ND & ND \\
\hline Terranova sep 96 & 7.07 & 28.0 & ND & 0.10 & 161 & 27 & ND & $\mathrm{ND}$ \\
\hline Calzadas sep 96 & 7.54 & 26.5 & ND & 0.10 & 225 & 250 & $\mathrm{ND}$ & $\mathrm{ND}$ \\
\hline Nanchital sep 96 & 7.48 & 26.7 & ND & 0.10 & 210 & 46 & ND & $\mathrm{ND}$ \\
\hline S. Francisco sep 96 & 7.50 & 26.8 & ND & 0.10 & 205 & 57 & ND & $\mathrm{ND}$ \\
\hline S. Antonio sep 96 & 7.53 & 26.7 & ND & 0.10 & 203 & 118 & ND & $\mathrm{ND}$ \\
\hline \begin{tabular}{|l|} 
Totoapa sep 96 \\
\end{tabular} & 7.64 & 26.3 & ND & 0.10 & 198 & 136 & $\mathrm{ND}$ & $\mathrm{ND}$ \\
\hline \begin{tabular}{|l|} 
Uxpanapa sep 96 \\
\end{tabular} & 7.70 & 26.1 & ND & 0.10 & 212 & 69 & $\overline{\mathrm{ND}}$ & $\mathrm{ND}$ \\
\hline Sta. Alejandrina sep 96 & 7.41 & 27.0 & ND & 0.10 & 220 & 117 & ND & $\overline{\mathrm{ND}}$ \\
\hline Capitanía sep 96 & 7.45 & 27.0 & ND & 0.10 & 222 & 55 & ND & $\mathrm{ND}$ \\
\hline Coachapa sep 96 & 7.48 & 27.0 & ND & 0.10 & 231 & 69 & ND & $\mathrm{ND}$ \\
\hline El Jícaro sep 96 & 7.46 & 27.1 & ND & 0.10 & 225 & 72 & ND & ND \\
\hline Boca jan 97 & 8.51 & 23.1 & ND & 35.10 & 202 & 2.0 & 6.36 & 3.55 \\
\hline \begin{tabular}{|l|} 
Astillero jan 97 \\
\end{tabular} & 8.32 & 21.9 & ND & 2.20 & 2.15 & 3.0 & 7.00 & 3.24 \\
\hline Gopalapa jan 97 & 8.46 & 23.2 & ND & 33.90 & 211 & 6.0 & 2.21 & 2.97 \\
\hline D. adentro jan 97 & 8.52 & 23.1 & 2.70 & 33.90 & 200 & 2.0 & 2.24 & 7.79 \\
\hline Teapa jan 97 & 8.42 & 22.9 & ND & 27.10 & 207 & 1.0 & 4.66 & 2.65 \\
\hline Terranova jan 97 & 7.9 & 22.7 & ND & 0.8 & 245 & 11.0 & 0.71 & 4.60 \\
\hline Calzadas jan 97 & 8.05 & 21.8 & ND & 2.10 & 222 & 5.0 & 2.01 & 0.86 \\
\hline Nanchital jan 97 & 8.53 & 23.2 & ND & 33.80 & 219 & 4.0 & 4.36 & 3.65 \\
\hline S. Francisco jan 97 & 8.01 & 22.0 & ND & 1.30 & 252 & 5.0 & 0.43 & 1.12 \\
\hline S. Antonio jan 97 & 8.0 & 24.5 & ND & 29.70 & 177 & 3.0 & 2.20 & 2.81 \\
\hline \begin{tabular}{|l|} 
Totoapa jan 97 \\
\end{tabular} & 7.96 & 21.7 & ND & 0.10 & 264 & 9.0 & 3.08 & 0.44 \\
\hline \begin{tabular}{|l|} 
Uxpanapa jan 97 \\
\end{tabular} & 8.08 & 21.7 & ND & 0.10 & 264 & 7.0 & 3.46 & 0.91 \\
\hline Sta. Alejandrina jan 97 & 7.75 & 22.0 & ND & 0.10 & 270 & 9.0 & 2.67 & 0.49 \\
\hline Capitanía jan 97 & 8.17 & 22.1 & ND & 0.10 & 275 & 11.0 & 2.91 & 0.41 \\
\hline Coachapa jan 97 & 7.69 & 22.5 & ND & 0.10 & 199 & 13.0 & 0.91 & 0.30 \\
\hline El Jícaro jan 97 & 8.58 & 22.5 & ND & 0.10 & 324 & 8.0 & 1.11 & 0.92 \\
\hline Boca apr 97 & 7.83 & 25.5 & 5.99 & 32.40 & 167 & 4.0 & 3.60 & 3.04 \\
\hline Astillero apr 97 & 7.93 & 25.5 & 5.81 & 33.20 & 182 & 9.0 & 1.26 & 8.98 \\
\hline \begin{tabular}{|l} 
Gopalapa apr 97 \\
\end{tabular} & 7.9 & 25.6 & 5.60 & 32.80 & 73.0 & 11.0 & 1.94 & 6.41 \\
\hline D. adentro apr 97 & 7.9 & 26.7 & 5.33 & 30.80 & 151 & 5.0 & 2.93 & 3.19 \\
\hline Terranova apr 97 & 7.41 & 26.3 & 4.30 & 9.60 & 184 & 13.0 & 5.90 & 1.93 \\
\hline \begin{tabular}{|l|} 
Nanachital apr 97 \\
\end{tabular} & 7.88 & 25.6 & 5.16 & 32.50 & 102 & 13.0 & 2.66 & 4.96 \\
\hline S. Francisco apr 97 & 7.65 & 26.4 & 3.30 & 25.30 & 169 & 5.0 & 0.22 & 3.95 \\
\hline S. Antonio apr 97 & 7.63 & 26.1 & 2.69 & 28.20 & 118 & 14.0 & 0.88 & 5.47 \\
\hline \begin{tabular}{|l|} 
Totoapa apr 97 \\
\end{tabular} & 7.35 & 25.4 & 0.41 & 24.60 & -35.0 & 6.0 & ND & 5.99 \\
\hline \begin{tabular}{|l} 
Uxpanapa apr 97 \\
\end{tabular} & 7.43 & 26.3 & 2.03 & 20.80 & 95.0 & 27.0 & $\mathrm{ND}$ & 3.93 \\
\hline Sta. Alejandrina apr 97 & 7.55 & 27.3 & 5.64 & 4.80 & 119 & 4.0 & 4.99 & 4.44 \\
\hline Capitanía apr 97 & 7.23 & 25.9 & 0.11 & 26.30 & -27.0 & 3.0 & 0.56 & 5.32 \\
\hline Coachapa apr 97 & 6.89 & 26.9 & 0.20 & 17.30 & 385 & 3.0 & 4.55 & 2.25 \\
\hline EI Jícaro apr 97 & 7.21 & 26.1 & 6.48 & 0.10 & 559 & 9.0 & 3.78 & 0.35 \\
\hline Boca aug 97 & 6.77 & 28.7 & 4.56 & 5.20 & 245 & 11.0 & 3.38 & 1.0 \\
\hline Astillero aug 97 & 6.96 & 28.5 & 4.80 & 0.70 & 137 & 22.0 & 0.49 & 1.30 \\
\hline \begin{tabular}{|l} 
D. adentro aug 97 \\
\end{tabular} & 7.26 & 28.8 & 6.28 & 1.80 & 166 & 12.0 & 0.13 & 1.43 \\
\hline Teapa aug 97 & 6.83 & 28.6 & 4.69 & 0.70 & 144 & 17.0 & 0.93 & 1.45 \\
\hline Terranova aug 97 & 6.72 & 29.2 & 3.01 & 0.20 & 127 & 44 & 1.72 & 2.59 \\
\hline Calzadas aug 97 & 6.83 & 28.5 & 4.06 & 7.40 & 139 & 12.0 & 1.17 & 2.05 \\
\hline Nanachital aug 97 & 6.81 & 28.6 & 3.36 & 0.30 & 153 & 18.0 & 0.93 & 0.95 \\
\hline S. Francisco aug 97 & 6.61 & 28.8 & 3.46 & 0.10 & 133 & 47.0 & 0.93 & 2.45 \\
\hline S. Antonio aug 97 & 6.51 & 28.9 & 4.42 & 0.10 & 184 & 20.0 & 2.57 & 1.06 \\
\hline \begin{tabular}{|l|} 
Totoapa aug 97 \\
\end{tabular} & 6.69 & 28.5 & 5.00 & 0.10 & 173 & 21.0 & 4.22 & 1.23 \\
\hline \begin{tabular}{|l|} 
Uxpanapa aug 97 \\
\end{tabular} & 6.87 & 28.1 & 4.97 & 0.10 & 168 & 23.0 & 21.77 & 1.11 \\
\hline Sta. Alejandrina aug 97 & 6.74 & 28.6 & 4.33 & 0.10 & 158 & 96.0 & 9.52 & 0.95 \\
\hline Capitanía aug 97 & 6.72 & 28.5 & 4.26 & 0.10 & 107 & 62.0 & 10.33 & 0.99 \\
\hline Coachapa aug 97 & 6.4 & 28.0 & 3.07 & 0.10 & 148 & 106 & 1.14 & 0.07 \\
\hline El Jícaro aug 97 & 6.76 & 27.4 & 1.64 & 0.10 & 88.0 & 167 & 0.78 & 0.71 \\
\hline
\end{tabular}

$\mathrm{T}=$ temperature $\left({ }^{\circ} \mathrm{C}\right) ; \mathrm{O}_{2}=$ dissolved oxygen $(\mathrm{mg} / \mathrm{l}) ; \mathrm{S}=$ salinity $(\mathrm{o} / \mathrm{oo}) ; \mathrm{Cu}=$ dissolved $\mathrm{Cu}(\mathrm{mg} / \mathrm{l}) ; \mathrm{Cr}=$ dissolved $\mathrm{Cr}(\mathrm{mg} / \mathrm{l})$, $\mathrm{ND}=$ undetermined

\section{METHODOLOGY AND LABORATORY WORK}

\section{Sediments}

Dry sieving of the sediments was carried out for the sand fraction (-1 to $4 \phi)$. Fractions $>$ to $4 \phi$ (silts and clays) were separated and the pipette method was used (KRUMBEIN AND

PETTIJOHN, 1938). Grain-size parameters were determined according to FOLK (1974) 
(Tables 2, 3, 4 and 5). Mode of sediments transport distributions (rolling, saltation and suspension) (VISHER, 1969) were determined by reading on probability plots and the results presented in percentages (Tables 2, 3, 4 and 5). This was done by each site during different sampling cycles to correlate between mode of sediment transport and heavy metal concentration. Determination of organic matter was based on the method by GAUDDETE and FLIGHT (1974) (Tables 2, 3, 4 and 5).

Table 2. Grain-size, mode of sediment transport and organic matter content of the Coatzacoalcos River sediments (september 1996)

\begin{tabular}{|l|c|c|c|c|c|c|}
\hline \multicolumn{1}{|c|}{ Station } & $\mathbf{M z}$ & $\sigma$ & $\begin{array}{c}\text { Roll } \\
(\mathbf{\%})\end{array}$ & $\begin{array}{c}\text { Salt } \\
(\mathbf{\%})\end{array}$ & $\begin{array}{c}\text { Susp } \\
(\mathbf{\%})\end{array}$ & $\begin{array}{c}\text { OM } \\
(\mathbf{\%})\end{array}$ \\
\hline Boca & 6.39 & 3.38 & 1.20 & 64.80 & 34.00 & 1.55 \\
\hline Astillero & 5.86 & 1.48 & 0.28 & 34.72 & 65.00 & 1.09 \\
\hline Terranova & 5.50 & 1.53 & 0.56 & 45.44 & 54.00 & 1.52 \\
\hline Gopalapa & 1.88 & 0.99 & 0.80 & 91.96 & 7.24 & 0.19 \\
\hline Calzadas & 5.73 & 1.41 & 1.30 & 46.70 & 52.00 & 1.02 \\
\hline Nanchital & 5.36 & 1.77 & 1.00 & 49.00 & 50.00 & 1.36 \\
\hline San Francisco & 5.92 & 1.44 & 0.15 & 35.85 & 64.00 & 1.19 \\
\hline San Antonio & 5.91 & 1.46 & 4.00 & 30.00 & 66.00 & 1.24 \\
\hline Uxpanapa & 5.63 & 1.72 & 0.50 & 65.50 & 34.00 & 1.67 \\
\hline Totoapa & 5.86 & 1.48 & 0.20 & 39.80 & 60.00 & 1.26 \\
\hline Santa Alejandrina & 6.44 & 1.62 & 0.28 & 23.72 & 76.00 & 1.53 \\
\hline Capitanía & 6.29 & 1.60 & 0.14 & 92.86 & 7.00 & 0.44 \\
\hline Coachapa & 5.92 & 1.42 & 0.02 & 35.98 & 64.00 & 1.41 \\
\hline Jícaro & 5.65 & 1.55 & 0.14 & 39.86 & 60.00 & 1.55 \\
\hline
\end{tabular}

$\mathrm{Mz}=$ grain-size, $\sigma=$ sorting; Roll= rolling $(\%)$; Salt= saltation $(\%), \mathrm{Susp}=$ suspension $(\%) ; \mathrm{OM}=$ organic matter content $(\%)$

Table 3. Grain-size, mode of sediment transport and organic matter content of the Coatzacoalcos River sediments (january 1997)

\begin{tabular}{|c|c|c|c|c|c|c|}
\hline Station & $\mathbf{M z}$ & $\sigma$ & $\begin{array}{l}\text { Roll } \\
(\%)\end{array}$ & $\begin{array}{l}\text { Salt } \\
(\%)\end{array}$ & $\begin{array}{l}\text { Susp } \\
(\%)\end{array}$ & $\begin{array}{l}\text { OM } \\
(\%)\end{array}$ \\
\hline Boca & 2.23 & 0.74 & 0.00 & 66.00 & 34.00 & 1.30 \\
\hline Dársena & 2.20 & 0.45 & 0.00 & 98.00 & 2.00 & 3.80 \\
\hline Astillero & 3.70 & 3.55 & 0.00 & 72.00 & 28.00 & 0.92 \\
\hline Teapa & 5.60 & 1.71 & 0.40 & 69.60 & 30.00 & 1.16 \\
\hline $\begin{array}{l}\text { Terranova } \\
\end{array}$ & 5.92 & 1.85 & 0.00 & 78.00 & 22.00 & 1.43 \\
\hline Gopalapa & 1.56 & 1.38 & 0.00 & 91.00 & 9.00 & 1.65 \\
\hline Calzadas & 6.92 & 1.47 & 0.06 & 25.94 & 74.00 & 1.28 \\
\hline Nanchital & 4.91 & 2.13 & 0.10 & 49.90 & 50.00 & 0.47 \\
\hline San Francisco & 4.87 & 2.19 & 0.28 & 79.72 & 20.00 & 0.97 \\
\hline San Antonio & 4.91 & 2.04 & 5.00 & 35.00 & 60.00 & 0.70 \\
\hline \begin{tabular}{|l} 
Uxpanapa \\
\end{tabular} & 4.90 & 1.30 & 0.04 & 88.96 & 11.00 & 0.20 \\
\hline Totoapa & 6.50 & 1.34 & 0.02 & 39.98 & 60.00 & 1.99 \\
\hline Santa Alejandrina & 5.62 & 1.84 & 0.20 & 57.80 & 42.00 & 1.56 \\
\hline Capitanía & 6.22 & 1.87 & 0.15 & 45.85 & 54.00 & $\overline{\mathrm{ND}}$ \\
\hline Coachapa & 5.27 & 2.08 & 0.08 & 61.92 & 38.00 & 0.57 \\
\hline Jícaro & 5.61 & 1.66 & 0.15 & 79.85 & 20.00 & 1.55 \\
\hline
\end{tabular}


Table 4. Grain-size, mode of sediment transport and organic matter content of the Coatzacoalcos River sediments (april 1997)

\begin{tabular}{|l|c|c|c|c|c|c|}
\hline \multicolumn{1}{|c|}{ Station } & Mz & $\sigma$ & $\begin{array}{c}\text { Roll } \\
(\mathbf{\%})\end{array}$ & $\begin{array}{c}\text { Salt } \\
(\mathbf{\%})\end{array}$ & $\begin{array}{c}\text { Susp } \\
(\mathbf{\%})\end{array}$ & $\begin{array}{c}\text { OM } \\
(\%)\end{array}$ \\
\hline Boca & 6.34 & 2.64 & 0.30 & 46.70 & 53.00 & 0.16 \\
\hline Dársena & 6.73 & 3.38 & 0.40 & 57.60 & 42.00 & 4.52 \\
\hline Dársena adentro & 8.79 & 4.30 & 0.80 & 61.20 & 38.00 & 1.19 \\
\hline Astillero & 6.95 & 3.47 & 0.40 & 57.60 & 42.00 & 1.72 \\
\hline Teapa & 7.15 & 2.43 & 4.37 & 73.63 & 26.37 & 0.92 \\
\hline Terranova & 7.55 & 2.94 & 0.28 & 27.72 & 72.00 & 1.72 \\
\hline Gopalapa & 5.33 & 2.62 & 0.80 & 61.20 & 38.00 & 1.28 \\
\hline Calzadas & 4.16 & 2.25 & 0.00 & 76.63 & $26-37$ & 0.50 \\
\hline Nanchital & 8.18 & 2.34 & 0.39 & 15.61 & 84.00 & 2.02 \\
\hline San Francisco & 5.16 & 2.18 & 0.14 & 69.86 & 30.00 & 0.88 \\
\hline San Antonio & 4.82 & 2.97 & 2.50 & 58.50 & 39.00 & 2.44 \\
\hline Uxpanapa & 7.28 & 2.57 & 1.00 & 51.00 & 48.00 & 1.57 \\
\hline Totoapa & 4.26 & 3.34 & 0.40 & 80.60 & 19.00 & 1.57 \\
\hline Capitanía & 5.84 & 3.33 & 0.00 & 40.00 & 60.00 & 1.07 \\
\hline Coachapa & 2.52 & 1.20 & 0.04 & 88.96 & 11.00 & 0.33 \\
\hline Jícaro & 7.48 & 2.69 & 0.50 & 25.50 & 74.00 & 1.61 \\
\hline
\end{tabular}

See Table 2 for symbols

Table 5. Grain-size, mode of sediment transport and organic matter content of the Cotzacoalcos River sediments (august 1997)

\begin{tabular}{|l|c|c|c|c|c|c|}
\hline \multicolumn{1}{|c|}{ Station } & $\mathbf{M z}$ & $\sigma$ & $\begin{array}{c}\text { Roll } \\
(\mathbf{\%})\end{array}$ & $\begin{array}{c}\text { Salt } \\
(\mathbf{\%})\end{array}$ & $\begin{array}{c}\text { Susp } \\
(\%)\end{array}$ & $\begin{array}{c}\text { OM } \\
(\mathbf{\%})\end{array}$ \\
\hline Boca & 6.82 & 3.71 & 1.0 & 67.00 & 32.00 & 1.49 \\
\hline Dársena & 2.24 & 0.61 & 0.60 & 23.10 & 76.30 & 0.29 \\
\hline Dársena adentro & 1.18 & 2.26 & 0.80 & 44.70 & 54.50 & 0.53 \\
\hline Astillero & 6.94 & 3.10 & 0.60 & 23.10 & 76.30 & 1.68 \\
\hline Teapa & 6.50 & 3.17 & 13.80 & 68.45 & 17.75 & 0.29 \\
\hline Terranova & 7.17 & 3.92 & 0.40 & 31.60 & 68.00 & 2.42 \\
\hline Gopalapa & 5.96 & 2.52 & 0.80 & 44.70 & 54.50 & 1.59 \\
\hline Calzadas & 3.86 & 2.16 & 3.80 & 68.45 & 27.75 & 1.68 \\
\hline Nanchital & 8.00 & 3.28 & 0.22 & 13.28 & 86.50 & 2.11 \\
\hline San Francisco & 6.09 & 2.91 & 0.15 & 45.85 & 54.00 & 1.25 \\
\hline San Antonio & 8.42 & 2.95 & 0.20 & 9.30 & 90.50 & 1.73 \\
\hline Uxpanapa & 6.73 & 3.22 & 1.00 & 45.00 & 55.00 & 1.54 \\
\hline Totoapa & 6.40 & 3.41 & 0.22 & 42.78 & 57.00 & 1.54 \\
\hline Santa Alejandrina & 7.61 & 3.00 & 0.32 & 10.68 & 89.00 & 1.58 \\
\hline Capitanía & 7.60 & 2.84 & 0.45 & 11.55 & 88.00 & 1.78 \\
\hline Coachapa & 5.01 & 3.65 & 2.63 & 45.22 & 52.15 & 0.67 \\
\hline Jícaro & 7.34 & 2.69 & 0.10 & 37.50 & 62.40 & 1.35 \\
\hline
\end{tabular}

See Table 2 for symbols

\section{Heavy metal concentration in sediments}

Determination of heavy metal concentration $(\mathrm{Cu}, \mathrm{Cr})$ in the Coatzacoalcos River sediments was carried out in a microwave oven following the Manual of Microwave Digestion System (CEM, 1994) using a Spectr AA-10 plus varian Atomic Absortion Spectrophotometer (Table 6). The sediment was dried at $55^{\circ} \mathrm{C}$ and grinded. The total concentration of each element was obtained in a microwave oven extracting the acid residue with $10 \mathrm{ml}$ of bidistilled water, $5 \mathrm{ml}$ of $\mathrm{HCO}_{3}$ and $2 \mathrm{ml}$ of $\mathrm{HCl}$ (BAHENA, 1999). The residues were centrifuged. A Northern Sea sediment classified as SDN 1/2 and certified by the Marine Radioactive Laboratory, Monaco was used for calibration. The accuracy of the method showed a relative error of $10 \%$ for $\mathrm{Cd}, 11.57 \%$ for $\mathrm{Co}, 3.87 \%$ for $\mathrm{Cu}$ and $1.62 \%$ for $\mathrm{Ni}$ (BAHENA, 1999). Heavy metal bioavailability (non-residual trace elements) was also determined by continuous extract of $1 \mathrm{~g}$. of sediment in $10 \mathrm{ml}$ of $\mathrm{HCl}$. The samples were 
centrifuged and trace elements $(\mathrm{Cu}, \mathrm{Cr})$ were detected with a Spectr AA-10 plus varian Atomic Absortion Spectrophotometer (Table 6).

Table 6. Total average $\mathrm{Cu}$ and $\mathrm{Cr}$ concentration and bioavailability values in the Coatzacoalcos River sediments

\begin{tabular}{|l|c|c|c|c|c|c|}
\hline Station & \multicolumn{2}{|c|}{$\begin{array}{c}\text { Total average } \\
\text { Cu and Cr } \\
\text { concentration }\end{array}$} & \multicolumn{2}{c|}{$\begin{array}{c}\text { Average Cu and Cr } \\
\text { bioavailability }\end{array}$} & \multicolumn{2}{c|}{$\begin{array}{c}\text { Non-residue heavy } \\
\text { metal contribution to } \\
\text { the total }\end{array}$} \\
\hline & $\mathbf{C u}$ & $\mathbf{C r}$ & $\mathbf{C u}$ & $\mathbf{C r}$ & $\mathbf{C u}$ & $\mathbf{C r}$ \\
\hline Boca & 26.83 & 59.74 & 10.80 & 5.00 & 40.47 & 8.40 \\
\hline Astillero & 26.02 & 71.47 & 7.70 & 4.20 & 29.77 & 5.99 \\
\hline Gopalapa & 16.55 & 49.04 & 6.30 & 3.70 & 35.76 & 7.60 \\
\hline Dársena adentro & 65.26 & 25.50 & 46.40 & 5.00 & 71.19 & 19.75 \\
\hline Dársena afuera & 21.39 & 50.25 & 5.00 & 1.90 & 23.38 & 3.95 \\
\hline Teapa & 59.35 & 54.05 & 36.60 & 6.60 & 61.70 & 12.25 \\
\hline Terranova & 29.51 & 69.99 & 10.50 & 7.00 & 35.74 & 10.07 \\
\hline Calzadas-Coatzacoalcos & 16.61 & 51.87 & 5.10 & 4.10 & 30.77 & 7.91 \\
\hline Nanchital & 44.61 & 59.07 & 8.60 & 4.40 & 19.31 & 7.50 \\
\hline San Francisco & 38.54 & 49.0 & 6.10 & 2.60 & 15.89 & 5.47 \\
\hline San Antonio & 45.05 & 65.68 & 9.10 & 3.90 & 20.36 & 5.93 \\
\hline Totoapa. & 46.81 & 64.33 & 6.00 & 4.30 & 20.39 & 5.95 \\
\hline Uxpanapa & 15.16 & 50.30 & 9.50 & 3.80 & 39.94 & 8.72 \\
\hline Santa Alejandrina & 24.97 & 54.52 & 8.90 & 3.40 & 36.0 & 6.27 \\
\hline Capitanía & 13.97 & 45.79 & 4.80 & 2.00 & 34.40 & 4.52 \\
\hline Coachapa & 6.77 & 25.15 & 3.40 & 2.00 & 43.56 & 8.08 \\
\hline Jícaro & 23.21 & 41.31 & 5.50 & 1.70 & 23.69 & 4.19 \\
\hline Average & 30.62 & 52.18 & 11.90 & 3.86 & 32.14 & 7.79 \\
\hline
\end{tabular}

$\mathrm{Cu}, \mathrm{Cr}$ values in ppm; non-residue contribution values in $\%$

Heavy metals in water

Disolved metals $(\mathrm{Cu}, \mathrm{Cr})$ in the water column were determined with a Spectr AA-10 plus varian Atomic Absortion Spectrophotometer following the standard methods (3131B), APHA, (1995) (Table 1).

Heavy metals in benthic fauna

Samples were prepared with 0.5 of biogenic residues following the Manual of Microwave Digestion System (CEM, 1994). $\mathrm{Mn}, \mathrm{Cr}, \mathrm{Cd}, \mathrm{Pb}, \mathrm{Co}, \mathrm{Cu}$ and $\mathrm{Ni}$ were determined using a Spectr AA-10 plus varian Atomic Absortion Spectrophotometer which was previously calibrated with Merk standards.

\section{RESULTS AND DISCUSSION}

The results showed that the Coatzacoalcos River sediments are composed of silts (average $\mathrm{Mz}=5.65 \phi$ ) that are transported mainly by suspension (Tables 2, 3, 4 and 5). Some sampling sites also showed sediments transported by saltation (Tables 2, 3, 4 and 5) especially during the second and third sampling cycles. Saltation takes place during low discharge cycles in dry seasons were the water unables the threshold of finer sediments as suspended loads. Most of the sampled sites were located downstream of the Coatzacoalcos River which concentrates finer sediments than the upstream. Nearby rivers to the Coatzacoalcos (i.e. Papaloapan River) also concentrate fine-grained sediments downstream and in the river mouth (ALVAREZ-RIVERA et al., 1986; ROSALES et al., 1986).

Heavy metals in sediments 
The Coatzacoalcos River sediments are potentially capable of trapping heavy metals since they are composed mainly by silts (YASUO, 1993).

Total average concentration of $\mathrm{Cr}$ and $\mathrm{Cu}$ in fine sediments of the Coatzacoalcos River was $52.18 \mu \mathrm{g} / \mathrm{g}$ and $30.62 \mu \mathrm{g} / \mathrm{g}$ respectively. The highest average values were reported for the Dársena Adentro, Teapa, Astillero and Nanchitlan locations (Table 6). Both values exceeded those found by ROSALES-HOZ AND CARRANZA-EDWARDS (1998) in the Coatzacoalcos River of $25.70 \mu \mathrm{g} / \mathrm{g}$ in sands and $39.35 \mu \mathrm{g} / \mathrm{g}$ in silts for $\mathrm{Cr}$ and $4.66 \mu \mathrm{g} / \mathrm{g}$ in sands and $25.46 \mu \mathrm{g} / \mathrm{g}$ in silts for $\mathrm{Cu}$. The highest concentration of $\mathrm{Cr}$ and $\mathrm{Cu}$ in sediments reported in this study is related to industrial sewage discharges close to the Dársena Adentro and Teapa locations (Table 6). The highest $\mathrm{Cr}$ concentration value alone was found in the Astillero station where ship maintenance activities are carried out. Also, the Nanchital station showed high concentration values for $\mathrm{Cr}(59.07 \mathrm{ppm})$ and $\mathrm{Cu}(44.61 \mathrm{ppm})$ (Table 6) probably due to the petrochemical activity of PEMEX (Mexican Oil Industry).

The highest average $\mathrm{Cr}$ and $\mathrm{Cu}$ bioavailability concentration values for the Dársena station were $5 \mathrm{ppm}$ and $46.40 \mathrm{ppm}$ respectively. The Teapa station reported $6.6 \mathrm{ppm}$ and $36.60 \mathrm{ppm}$ for $\mathrm{Cr}$ and $\mathrm{Cu}$ respectively (Table 6). Both localities are impacted by industrial and urban discharges.

\section{Multiple correlation}

A multiple correlation at $95 \%$ significance level between the sediments, grain-size parameters, modes of sediment transport, organic matter, total $\mathrm{Cu}$ and $\mathrm{Cr}$ concentrations and $\mathrm{Cu}$ and $\mathrm{Cr}$ bioavailability values was carried out (Tables 7, 8, 9 and 10).

The first sampling (september 1996) showed a positive correlation between Mz, suspension, total $\mathrm{Cu}$ and $\mathrm{Cr}$ concentrations and bioavailability and organic matter content (Table 7). This suggests that during the rainy season sediments in the Coatzacoalcos River are transported mainly by suspension and that high $\mathrm{Cu}$ and $\mathrm{Cr}$ values are related to high percentages of silt and clay fractions and organic matter in the sediments. Antrophogenic influence is controlling the high $\mathrm{Cu}$ and $\mathrm{Cr}$ values in the sediments. A positive correlation is also shown between the silt and clay fraction, organic matter content and $\mathrm{Cu}$ and $\mathrm{Cr}$ values (Table 7).

The second sampling (january 1997) showed little correlation with the rest of the parameters (Table 8). Only the clay fraction has a positive correlation with the suspension (Table 8). This implies that during intermittent storms in january, clays might be resuspended into the water column due to heavy discharge inputs. 
The third sampling (april 1997) showed that the sand and silt fractions have a positive correlation with saltation and suspension respectively (Table 9). There is also a high correlation between total $\mathrm{Cu}$ and $\mathrm{Cr}$ in bottom waters and organic matter content (Table 9). This indicates that finer sediments concentrate higher organic matter content (ORTIZZAMORA AND CARRANZA-EDWARDS, 1997) which also allows high concentration of heavy metals.

The fourth sampling (september 1997) showed that Mz has a positive correlation with suspension, $\mathrm{Cr}$ concentration and organic matter content (Table 10). Also, the silt and clay fractions correlates with suspension, $\mathrm{Cr}$ concentration and organic matter content (Table 10). These correlations followed a similar pattern to those showed during the first sampling in september (Tables 7 and 10).

Table 7. Multiple correlation among sediments, mode of sediment transport, $\mathrm{Cu}$ and $\mathrm{Cr}$ concentration and bioavailability values and organic matter content (september 1996).

\begin{tabular}{|l|l|l|l|l|l|l|l|l|l|l|l|l|l|}
\hline & Sand & Silt & Clay & $\mathbf{M z}$ & $\sigma$ & Roll & Salt & $\begin{array}{l}\text { Susp } \\
\text { Total } \\
\text { Cu }\end{array}$ & $\begin{array}{l}\text { Total } \\
\text { Cr }\end{array}$ & $\begin{array}{l}\text { Cu } \\
\text { Bio }\end{array}$ & $\begin{array}{l}\text { Cr } \\
\text { Bio }\end{array}$ & OM \\
\hline Sand & 1.00 & -0.96 & -0.42 & -0.94 & -0.18 & -0.05 & 0.82 & -0.82 & -0.71 & -0.84 & -0.45 & 0.15 & -0.78 \\
\hline Silt & & 1.00 & 0.16 & 0.81 & -0.07 & 0.05 & -0.82 & 0.82 & 0.55 & 0.78 & 0.25 & -0.23 & 0.66 \\
\hline Clay & & & 1.00 & 0.69 & 0.90 & 0.02 & -0.24 & 0.24 & 0.76 & 0.46 & 0.81 & 0.23 & 0.64 \\
\hline Mz & & & & 1.00 & 0.47 & 0.04 & -0.76 & 0.76 & 0.84 & 0.86 & 0.68 & -0.02 & 0.85 \\
\hline$\sigma$ & & & & & 1.00 & 0.05 & 0.10 & -0.11 & 0.50 & 0.35 & 0.73 & 0.38 & 0.54 \\
\hline Roll & & & & & & 1.00 & -0.11 & 0.05 & 0.11 & 0.02 & 0.37 & 0.38 & -0.05 \\
\hline Salt & & & & & & & 1.00 & -1.00 & -0.72 & -0.68 & -0.41 & 0.20 & -0.48 \\
\hline Susp & & & & & & & & 1.00 & 0.72 & 0.68 & 0.39 & -0.22 & 0.49 \\
\hline Total Cu & & & & & & & & & 1.00 & 0.68 & 0.77 & 0.14 & 0.69 \\
\hline Total Cr & & & & & & & & & & 1.00 & 0.65 & 0.03 & 0.69 \\
\hline Cu Bio & & & & & & & & & & & 1.00 & 0.59 & 0.59 \\
\hline Cr Bio & & & & & & & & & & & & 1.00 & 0.12 \\
\hline OM & & & & & & & & & & & & & 1.00 \\
\hline
\end{tabular}

See Table 2 for symbols; Bio=bioavailability; $95 \%$ confidence level

Table 8. Multiple correlation among sediments, mode of sediment transport, $\mathrm{Cu}$ and $\mathrm{Cr}$ concentration and bioavailability values and organic matter content (january 1997).

\begin{tabular}{|c|c|c|c|c|c|c|c|c|c|c|c|c|c|c|c|}
\hline & Sand & Silt & Clay & $\overline{\mathrm{Mz}}$ & $\sigma$ & Roll & Salt & Susp & $\begin{array}{l}\text { Total } \\
\mathrm{Cu}\end{array}$ & \begin{tabular}{|l} 
Total \\
$\mathrm{Cr}$
\end{tabular} & \begin{tabular}{|l|}
$\mathrm{Cu}$ \\
Bio
\end{tabular} & \begin{tabular}{|l|}
$\mathrm{Cr}$ \\
$\mathrm{Bio}$
\end{tabular} & \begin{tabular}{|l}
$\begin{array}{l}\mathrm{Cu} \\
\text { wat }\end{array}$ \\
\end{tabular} & \begin{tabular}{|l}
$\begin{array}{l}\mathrm{Cr} \\
\text { wat }\end{array}$ \\
\end{tabular} & $\overline{O M}$ \\
\hline Sand & 1.00 & -0.95 & -0.62 & 0.33 & -0.34 & 0.08 & 0.35 & -0.45 & 0.16 & 0.12 & 0.13 & -0.15 & 0.23 & & \begin{tabular}{|l|l|}
0.40 \\
\end{tabular} \\
\hline Silt & & 1.00 & 0.37 & \begin{tabular}{|c|c|} 
\\
\end{tabular} & \begin{tabular}{|l|l|}
0.14 \\
\end{tabular} & \begin{tabular}{|c|}
-0.10 \\
-10
\end{tabular} & -0.21 & 0.31 & -0.15 & -0.22 & -0.11 & 0.19 & \begin{tabular}{|l|l|}
-0.27 \\
\end{tabular} & -0.63 & \begin{tabular}{|l|}
-0.37 \\
\end{tabular} \\
\hline Clav & & & 1.00 & -0.26 & 0.39 & 0.03 & -0.58 & 0.66 & -0.04 & \begin{tabular}{|l|}
0.18 \\
\end{tabular} & -0.09 & -0.02 & -0.24 & -0.06 & -0.20 \\
\hline$\overline{M z}$ & & & & 1.00 & -0.35 & -0.08 & -0.12 & 0.17 & -0.06 & -0.06 & 0.07 & 0.01 & 0.47 & 0.23 & \begin{tabular}{|l|}
-0.07 \\
\end{tabular} \\
\hline $\bar{\sigma}$ & & & & & \begin{tabular}{|l|}
1.00 \\
\end{tabular} & 0.13 & -0.20 & 0.13 & 0.44 & -0.16 & -0.40 & -0.24 & 0.13 & 0.4 & -0.55 \\
\hline Roll & & & & & & 1.00 & -0.44 & -0.15 & -0.41 & 0.03 & 0.01 & 0.02 & -0.13 & 0.12 & \begin{tabular}{|l|}
-0.23 \\
\end{tabular} \\
\hline Salt & & & & & & & 1.00 & -0.82 & 0.16 & -0.20 & 0.15 & 0.20 & -0.03 & 0.24 & -0.48 \\
\hline Susp & & & & & & & & 1.00 & 0.15 & 0.20 & -0.14 & -0.22 & 0.10 & $\overline{-0.36}$ & 0.20 \\
\hline Total Cu & & & & & & & & & 1.00 & 0.20 & 0.14 & 0.03 & -0.03 & 0.17 & -0.08 \\
\hline Total $\mathrm{Cr}$ & & & & & & & & & & 1.00 & $\overline{0.32}$ & 0.48 & \begin{tabular}{|l|}
0.09 \\
\end{tabular} & 0.34 & \begin{tabular}{|l|}
-0.08 \\
\end{tabular} \\
\hline Cu Bio & & & & & & & & & & & 1.00 & 0.54 & 0.33 & 0.30 & 0.34 \\
\hline Cr Bio & & & & & & & & & & & & 1.00 & 17 & 0.41 & 0.42 \\
\hline C & & & & & & & & & & & & & \begin{tabular}{|l|l}
1.00 \\
\end{tabular} & 0.38 & $\mid-0.11$ \\
\hline Crwat & & & & & & & & & & & & & & 1.00 & 0.03 \\
\hline & & & & & & & & & & & & & & & 1.00 \\
\hline
\end{tabular}

See Table 2 for symbols; Bio=bioavailability; wat=bottom water 
Table 9. Multiple correlation among sediments, mode of sediment transport, $\mathrm{Cu}$ and $\mathrm{Cr}$ concentration and bioavailability values and organic matter content (april 1997).

\begin{tabular}{|c|c|c|c|c|c|c|c|c|c|c|c|c|c|c|c|}
\hline & Sand & \begin{tabular}{|l|} 
Silt \\
\end{tabular} & Clay & Mz & $\bar{\sigma}$ & Roll & Salt & Susp & $\begin{array}{l}\text { Total } \\
\mathrm{Cu} \\
\end{array}$ & \begin{tabular}{|l|} 
Total \\
$\mathrm{Cr}$
\end{tabular} & 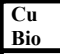 & \begin{tabular}{|l}
$\begin{array}{l}\mathrm{Cr} \\
\mathrm{Bio}\end{array}$ \\
Ben
\end{tabular} & \begin{tabular}{|l}
$\begin{array}{c}\mathrm{Cu} \\
\text { wat }\end{array}$ \\
\end{tabular} & $\begin{array}{l}\mathrm{Cr} \\
\text { wat }\end{array}$ & OM \\
\hline Sand & 1.00 & -0.95 & -0.93 & -0.71 & -0.63 & 0.21 & 0.67 & -0.68 & & -0.26 & & -0.38 & -0.24 & & $\mid-0.26$ \\
\hline Silt & & 1.00 & 0.77 & -0.57 & 0.58 & -0.34 & -0.56 & 0.56 & 0.41 & 0.25 & 0.31 & $\overline{0.34}$ & 0.21 & -0.02 & 0.16 \\
\hline Clay & & & 1.00 & 0.80 & 0.60 & -0.09 & -0.74 & 0.74 & 0.61 & 0.23 & 0.52 & 0.38 & 0.24 & -0.01 & 0.34 \\
\hline$\overline{M z}$ & & & & 1.00 & 0.32 & -0.21 & -0.81 & 0.81 & 0.70 & 0.02 & 0.64 & 0.33 & 0.59 & -0.35 & -0.15 \\
\hline$\sigma$ & & & & & 1.00 & -0.27 & \begin{tabular}{|l|}
-0.33 \\
\end{tabular} & $\begin{array}{l}0.33 \\
\end{array}$ & $\begin{array}{ll}0.62 \\
\end{array}$ & 0.08 & 0 & $1-0.05$ & $\mid-0.20$ & $\begin{array}{ll}0.26 \\
\end{array}$ & \begin{tabular}{|l|l|l|}
0.34 \\
\end{tabular} \\
\hline Roll & & & & & & 1.00 & -0.04 & 0.03 & -0.26 & 0.21 & -0.26 & 0.06 & -0.15 & 0.21 & 0.05 \\
\hline Salt & & & & & & & 1.00 & -1.00 & -0.40 & -0.16 & -0.32 & -0.44 & -0.24 & 0.28 & $\mid-0.12$ \\
\hline Susp & & & & & & & & $\begin{array}{l}1.00 \\
\end{array}$ & 0 & $\begin{array}{l}0.17 \\
\end{array}$ & 0.33 & 0.44 & 0.25 & \begin{tabular}{|l|l|}
-0.29 \\
\end{tabular} & 0.11 \\
\hline TotalCu & & & & & & & & & 1.00 & \begin{tabular}{|l|}
-0.16 \\
\end{tabular} & 0.98 & 0.12 & 0.18 & -0.13 & 0.15 \\
\hline TotalCr & & & & & & & & & & 1.00 & -0.33 & 0.65 & -0.08 & 0.49 & 0.59 \\
\hline \begin{tabular}{|l|} 
Cu Bio \\
\end{tabular} & & & & & & & & & & & \begin{tabular}{|l|l|}
1.00 \\
\end{tabular} & \begin{tabular}{|l|l|}
-0.03 \\
\end{tabular} & \begin{tabular}{|l|l|} 
\\
\end{tabular} & -0.14 & \begin{tabular}{|l}
0.03 \\
\end{tabular} \\
\hline Cr Bio & & & & & & & & & & & & 1.00 & 0.39 & 0.11 & 0.30 \\
\hline Cu wat & & & & & & & & & & & & & 1.00 & \begin{tabular}{|c|}
-0.68 \\
\end{tabular} & \begin{tabular}{|l|l|}
-0.38 \\
\end{tabular} \\
\hline Crwat & & & & & & & & & & & & & & 1.00 & 0.68 \\
\hline & & & & & & & & & & & & & & & 1.00 \\
\hline
\end{tabular}

See Table 8 for symbols

Table 10. Multiple correlation among sediments, mode of sediment transport, $\mathrm{Cu}$ and $\mathrm{Cr}$ concentration and bioavailability values and organic matter content (august 1997).

\begin{tabular}{|l|l|l|l|l|l|l|l|l|l|l|l|l|l|l|l|}
\hline & Sand & Silt & Clay & $\mathbf{M z}$ & $\sigma$ & Roll & Salt & Susp & $\begin{array}{l}\text { Total } \\
\text { Cu }\end{array}$ & $\begin{array}{l}\text { Total } \\
\text { Cr }\end{array}$ & $\begin{array}{l}\text { Cu } \\
\text { Bio }\end{array}$ & $\begin{array}{l}\text { Cr } \\
\text { Bio }\end{array}$ & $\begin{array}{l}\text { Cu } \\
\text { wat }\end{array}$ & $\begin{array}{l}\text { Cr } \\
\text { wat }\end{array}$ & OM \\
\hline Sand & 1.00 & -0.96 & -0.95 & -0.93 & -0.67 & 0.36 & 0.86 & -0.87 & -0.35 & -0.49 & -0.19 & 0.10 & -0.15 & 0.25 & -0.70 \\
\hline Silt & & 1.00 & 0.87 & 0.92 & 0.65 & -0.35 & -0.80 & 0.80 & 0.41 & 0.57 & 0.23 & -0.15 & 0.16 & -0.14 & 0.69 \\
\hline Clay & & & 1.00 & 0.93 & 0.62 & -0.36 & -0.92 & 0.92 & 0.29 & 0.50 & 0.14 & -0.17 & 0.18 & -0.37 & 0.65 \\
\hline Mz & & & & 1.00 & 0.65 & -0.20 & -0.90 & 0.88 & 0.37 & 0.65 & 0.19 & -0.24 & 0.25 & -0.17 & 0.77 \\
\hline$\sigma$ & & & & & 1.00 & -0.07 & -0.56 & 0.54 & 0.27 & 0.09 & 0.23 & 0.13 & 0.09 & -0.12 & 0.60 \\
\hline Roll & & & & & & 1.00 & 0.32 & -0.44 & -0.32 & -0.18 & -0.23 & -0.14 & 0.37 & 0.11 & 0.09 \\
\hline Salt & & & & & & & 1.00 & -0.99 & -0.31 & -0.48 & -0.18 & 0.18 & -0.19 & 0.21 & -0.71 \\
\hline Susp & & & & & & & & 1.00 & 0.34 & 0.48 & 0.21 & -0.15 & 0.12 & -0.21 & 0.65 \\
\hline TotalCu & & & & & & & & & 1.00 & 0.32 & 0.97 & 0.34 & -0.09 & 0.10 & 0.32 \\
\hline TotalCr & & & & & & & & & & 1.00 & 0.13 & -0.26 & 0.21 & 0.20 & 0.56 \\
\hline Cu Bio & & & & & & & & & & & 1.00 & 0.45 & -0.14 & 0.07 & 0.22 \\
\hline Cr Bio & & & & & & & & & & & & 1.00 & -0.31 & 0.40 & 0.16 \\
\hline Cu wat & & & & & & & & & & & & & 1.00 & -0.18 & 0.21 \\
\hline Cr wat & & & & & & & & & & & & & & 1.00 & 0.36 \\
\hline OM & & & & & & & & & & & & & & & 1.00 \\
\hline
\end{tabular}

See Table 8 for symbols

Physical parameters and heavy metal concentrations.

The physical parameters $\left(\mathrm{pH}, \mathrm{T}^{\circ} \mathrm{C}, \mathrm{O}_{2}, \mathrm{~S} \%\right.$, Eh, turbidness) measured in the Coatzacoalcos River and metal concentrations $(\mathrm{Cu}, \mathrm{Cr})$ are shown in Table 1.

Average extreme $\mathrm{pH}$ values were reported for august $1997(\mathrm{pH}=6.76)$ and january $1997(\mathrm{pH}=8.18)$. The highest $\mathrm{pH}$ value was observed for the Dársena Adentro station in january $1997(\mathrm{pH}=9.27)$ (Table 1) which exceeded the values reported in Canada for life protection ( $\mathrm{pH}=6.5-9.0)$ (CHAPMAN AND KIMSTACH, 1992).

The water temperature varied from $21.7^{\circ} \mathrm{C}$ in january to $29.2^{\circ} \mathrm{C}$ in august. Guerra (1990) and GONZALES, M. et al., 1994) reported temperature values of $21.3^{\circ} \mathrm{C}$ in february and $31.3^{\circ} \mathrm{C}$ in august in the river which do not show high discrepancies to the values found in this study (Table 1). However high water temperatures are probably associated to industrial discharges (MÉNDEZ, 1998)

Low dissolved $\mathrm{O}_{2}$ values $(0-6.48 \mathrm{mg} / \mathrm{l})$ in the water column of the Coatzacoalcos River were determined in april and august (Table 1). The locations with the lowest $\mathrm{O}_{2}$ dissolved values were the Capitanía and Coachapa stations (0.11-0.20 mg/l respectively) (Table 1). 
Low dissolved $\mathrm{O}_{2}$ values in the water column are due to little turbulence in the water column, organic matter oxidation and microbial activity (CHAPMAN AND KIMSTACH, 1992). In general, the average dissolved $\mathrm{O}_{2}$ values in the water of the Coatzacoalcos River were $3.82 \mathrm{mg} / \mathrm{l}$ in april and $4.06 \mathrm{mg} / \mathrm{l}$ in august. Similar average values were determined by MÉNDEZ (1998) in april 1998 (3.62 mg/l) in the Coatzacoalcos River. This probably indicates little turbulence in the water during the dry season (april) and also high microbial activity due to industrial discharges (CHAPMAN AND KIMSTACH, 1992; MÉNDEZ, 1998). A low dissolved $\mathrm{O}_{2}$ value in the water column of the river has also depleted the number of benthic organisms as it will be reported further in this study.

Average salinity values were $0.85 \%$ and $22.02 \%$ in august and april respectively (Table 1). Highest salinity values in the water column are associated to the dry season.

Redox potential (Eh) values showed inconsistencies especially in areas of industrial discharges like Dársena Adentro and Totoapa (Table 1).

The highest average disolved $\mathrm{Cr}$ and $\mathrm{Cu}$ values in the water were observed during the dry season (april 1997) for the Nanchital $(\mathrm{Cr}=4.96 \mathrm{mg} / \mathrm{l})$, Astillero $(\mathrm{Cr}=8.98 \mathrm{mg} / \mathrm{l})$, $\mathrm{Sn}$. Antonio $(\mathrm{Cr}=5.47 \mathrm{mg} / \mathrm{l})$, Totoapa $(\mathrm{Cr}=5.99 \mathrm{mg} / \mathrm{l})$ and Boca $(\mathrm{Cu}=6.36 \mathrm{mg} / \mathrm{l})$, Dársena Adentro $(\mathrm{Cu}=9.10 \mathrm{mg} / \mathrm{l})$, Nanchital $(\mathrm{Cu}=4.36 \mathrm{mg} / \mathrm{l})$, Terranova $(\mathrm{Cu}=5.90 \mathrm{mg} / \mathrm{l})$, Teapa $(\mathrm{Cu}=$ $4.66 \mathrm{mg} / \mathrm{l}$ in january 1997), Astillero $(\mathrm{Cu}=7.0 \mathrm{mg} / \mathrm{l})$ and Sta. Alejandrina $(\mathrm{Cu}=4.99 \mathrm{mg} / \mathrm{l}$ and $9.52 \mathrm{mg} / \mathrm{l}$ in august 1997) (Table 1). These stations exceeded the $\mathrm{Cu}$ and $\mathrm{Cr}$ values in water reported in Canada for life protection (4.00 mg/l) (CHAPMAN AND KIMSTACH, 1992), and those reported in polluted-free waters $(<0.5 \mathrm{mg} / \mathrm{l})($ SADIQ, 1992) (Table 1). The highest dissolved $\mathrm{Cr}$ and $\mathrm{Cu}$ values in water were determined in april (dry season) with the exception of one station (Uxpanapa) (Fig. 2) in which a dissolved $\mathrm{Cu}$ value of $21.77 \mathrm{mg} / \mathrm{l}$ was observed in august 1997 (Table 1). KONHAUSER et al. (1997) reported dissolved $\mathrm{Cu}$ values of 2.5 $\mathrm{mg} / 1$ to $17.9 \mathrm{mg} / \mathrm{l}$ in the Mahanadi River and dissolved $\mathrm{Cr}$ values of $2.6 \mathrm{mg} / 1$ to $18.6 \mathrm{mg} / \mathrm{l}$ for the Brahmani River in India. Both rivers are impacted by industrial and urban discharges.

\section{Benthic fauna}

A systematic count of benthic fauna was carried out for the january 1997 sampling since little recovery of organisms was achieved for the rest of the sampling cycles (Table 11). 
Table 11. Benthic fauna in the Coatzacoalcos River

\begin{tabular}{|c|c|c|c|}
\hline Station & Family & Genera & Number recovered \\
\hline Dársena & Corbulidae * & Corbula (Caryocorbula) & 4 \\
\hline Dársena & Semelidae * & Abra aequalis & 1 \\
\hline Dársena & Pilargidae $* * *$ & Parandalia vivianneae & 37 \\
\hline Astillero & Mytilidae * & Modiolus americanus & 7 \\
\hline Astillero & Neritidae ** & Neritina reclivata & 88 \\
\hline Astillero & Neritidae ** & Neritina virginea & 20 \\
\hline Astillero & Ostreidae * & Crassostrea virginica & 15 \\
\hline Astillero & Poliqueto $* * *$ & Nereis $s p$ & 3 \\
\hline Astillero & Corbiculidae * & Polymesoda caroliniana & 7 \\
\hline Astillero & Ostreidae * & Rangia flexuosa & 14 \\
\hline Astillero & Corbulidae * & Corbula spp & 1 \\
\hline Teapa & Corbulaide * & Corbula (Caryocorbula) & 2 \\
\hline Teapa & Cuspidariidae * & Cuspidaria $s p$ & 3 \\
\hline Teapa & Neritidae ** & Neritina reclivata & 1 \\
\hline Teapa & **** & Nereis $s p$ & 1 \\
\hline Teapa & Semelidae * & Abra aequalis & 1 \\
\hline Terranova & Parapseudidae $* * * *$ & Discapseudes holthuisi & 7 \\
\hline Terranova & **** & Nereis $s p$ & 1 \\
\hline Terranova & & Crustacean debri & 1 \\
\hline Gopalapa & Corbulidae * & Corbula (Caryocorbula) & 3 \\
\hline Gopalapa & Apseudidae & & 1 \\
\hline Calzadas & Neritidae ** & Neritina reclivata & 52 \\
\hline Calzadas & Ostreidae * & Crassostrea virginica & 2 \\
\hline Calzadas & Apseudidae & & \\
\hline Nanchital & Neritidae ** & Neritina reclivata & 1 \\
\hline Nanchital & Apseudidae & & 4 \\
\hline Nanchital & Pilargidae $* * *$ & Parandalia vivianneae & 5 \\
\hline San Francisco & Parapseudidae $* * * *$ & Discapseudes holthuisi & 4 \\
\hline San Francisco & Pilargidae $* * *$ & Parandalia vivianae & 8 \\
\hline San Antonio & Apsudidae & & 1 \\
\hline San Antonio & Neritidae ** & Neritina reclivata & 14 \\
\hline
\end{tabular}

* bivalve; ** gastropod; *** polychaete; **** crustacea

The low preservation of benthic fauna is due to the intense dredging activity in the last two decades and $\mathrm{O}_{2}$ poor waters that have depleted the benthic communities in the Coatzacoalcos River (GONZALES et al., 1994). Therefore only heavy metal concentration was determined in Rangia cuneata, Rangia flexuosa and Polimesoda carolineana at Astillero station. These three species concentrated $300.28 \mu \mathrm{g} / \mathrm{g}$ and $93.93 \mu \mathrm{g} / \mathrm{g}$ of Mn respectively (Tables 12 and 13).

BOTELLO et al. (1996) found $148 \mu \mathrm{g} / \mathrm{g}$ and $172 \mu \mathrm{g} / \mathrm{g}$ of Mn values in Rangia flexuosa and Polimesoda carolineana. The Mn values obtained in this study exceeded in $100 \%$ the $\mathrm{Mn}$ values obtained by BOTELLO et al. (1996). The Mn values in Rangia cuneata and Rangia flexuosa are below the values obtained by the same author. High Mn values can be hazardous 
for human consumption although no legislation has been issued for $\mathrm{Mn}$ in organisms (VILLANUEVA AND PAEZ-OSUNA, 1996).

The $\mathrm{Pb}$ concentration value in Rangia cuneata and Rangia flexuosa was $16.38 \mu \mathrm{g} / \mathrm{g}$ and $4.94 \mu \mathrm{g} / \mathrm{g}$ in Polimesoda carolineana (Tables 12 and 13). The three species exceeded the values allowed by the Health Department of Australia of $2.5 \mu \mathrm{g} / \mathrm{g}$ for $\mathrm{Pb}$ concentration in organisms.

The Co concentration value in Rangia cuneata and Rangia flexuosa was $10.92 \mu \mathrm{g} / \mathrm{g}$ and $9.89 \mu \mathrm{g} / \mathrm{g}$ in Polimesoda carolineana (Tables 12 and 13). BOTELLO et al. (1996) reported for Co in Melongena melongena a concentration value of $13.57 \mu \mathrm{g} / \mathrm{g}$. Nevertheless, these values are not considered hazardous since similar Co concentration values in organisms have been reported in polluted-free areas (BOTELLO et al, 1996)

The Ni concentration value in Rangia cuneata and Rangia flexuosa was $10.92 \mu \mathrm{g} / \mathrm{g}$ and $4.94 \mu \mathrm{g} / \mathrm{g}$ in Polimesoda carolineana (Tables 12 and 13). Since Ni is a highly mobile element it is less capable of being accumulated in organisms (SADIQ, 1992). In this study Ni values in the organisms can be related to $\mathrm{Ni}$ values concentrated in the sediments.

The $\mathrm{Cu}$ concentration value in Rangia cuneata and Rangia flexuosa was $10.92 \mu \mathrm{g} / \mathrm{g}$ and $9.89 \mu \mathrm{g} / \mathrm{g}$ in Polimesoda carolineana (Tables 12 and 13). The highest $\mathrm{Cu}$ concentration value in organisms allowed by the Health Department of Australia is $150 \mu \mathrm{g} / \mathrm{g}$. The values obtained in this study are within the normal standard range.

The Cr concentration value in Rangia cuneata and Rangia flexuosa was $10.92 \mu \mathrm{g} / \mathrm{g}$ and $9.89 \mu \mathrm{g} / \mathrm{g}$ in Polimesoda carolineana (Tables 12 and 13). Cr concentration value in the water and sediments in the Astillero station were $3.24 \mu \mathrm{g} / \mathrm{g}$ and $71.47 \mu \mathrm{g} / \mathrm{g}$ respectively (Tables 1 and 6) Cr concentration values in the water, sediments and organisms exceeded the values allowed by the Urban Services Department Headquarters of Japan of $1.0 \mu \mathrm{g} / \mathrm{g}$ (NAUEN, 1996). However some organisms like oysters can tolerate between 100 and 300 $\mu \mathrm{g} / \mathrm{g}$ of Cr concentration (ROSAS et al. 1983; VILLANUEVA et al., 1996).

No Cd values were detected in the benthic fauna of the Coatzacoalcos River (Tables 12 and 13).

Table 12. Heavy metal concentration in benthic fauna at the Astillero station (january, 1997)

\begin{tabular}{|l|c|c|c|c|c|c|c|}
\hline \multicolumn{1}{|c|}{ Benthic fauna } & Mn & $\mathbf{C r}$ & $\mathbf{C d}$ & $\mathbf{P b}$ & $\mathbf{C o}$ & $\mathbf{C u}$ & $\mathbf{N i}$ \\
\hline Rangia cuneata and R. flexuosa & 300.28 & 10.92 & ND & 16.38 & 10.92 & 10.92 & 10.92 \\
\hline Polimesoda carolineana & 93.93 & 9.89 & ND & 4.94 & 9.89 & 9.89 & 4.94 \\
\hline
\end{tabular}


Table 13. Heavy metal concentration in water, sediments and benthic fauna from the Astillero and Jicaro Stations (january 1997).

\begin{tabular}{|l|c|c|c|c|c|c|}
\hline Element & $\begin{array}{c}\text { Bottom Water } \\
\text { Astillero }\end{array}$ & $\begin{array}{c}\text { Bottom Water } \\
\text { Jícaro }\end{array}$ & $\begin{array}{c}\text { Total sediment } \\
\text { Astillero }\end{array}$ & $\begin{array}{c}\text { Total sediment } \\
\text { Jícaro }\end{array}$ & $\begin{array}{c}\text { Polimesoda } \\
\text { carolineana }\end{array}$ & $\begin{array}{c}\text { Rangia cuneata } \\
\text { and } \text { R. flexuosa }\end{array}$ \\
\hline $\mathbf{M n}$ & NS & NS & 500 & 200 & 93.93 & 300.28 \\
\hline $\mathbf{C r}$ & 3.24 & 0.92 & 57.30 & 19.18 & 9.89 & 10.92 \\
\hline $\mathbf{C d}$ & NS & NS & 4.67 & 2.30 & ND & ND \\
\hline $\mathbf{P b}$ & NS & NS & 49.83 & 52.98 & 4.94 & 16.38 \\
\hline $\mathbf{C o}$ & NS & NS & 17.44 & 18.43 & 9.89 & 10.92 \\
\hline $\mathbf{C u}$ & 7 & 1.11 & 13.7 & 4.70 & 9.89 & 10.92 \\
\hline $\mathbf{N i}$ & NS & NS & 24.90 & 16.45 & 4.95 & 10.92 \\
\hline
\end{tabular}

$\mathrm{ND}=$ undetermined $\mathrm{NS}=$ unsampled; Bottom water $=\mu \mathrm{g} / \mathrm{l} ;$ Total sediment $=\mathrm{mg} / \mathrm{Kg}$ Polimesoda carolineana $=\mathrm{mg} / \mathrm{Kg} ;$ Rangia cuneata and R. flexuos $a=\mathrm{mg} / \mathrm{Kg}$

Rangia concentrates 1.1 times more $\mathrm{Cu}$ than $\mathrm{Cr}$ than Polimesoda in sediments (Table 14). Polimesoda carolineana, Rangia cuneata and Rangia flexuosa concentrate 2.2 times more $\mathrm{Cr}$ than $\mathrm{Cu}$ in water (Table 15). Rangia also concentrates 4.2 times more $\mathrm{Cu}$ than $\mathrm{Cr}$ in sediments (Table 16).

This probably indicates that the three species have an efficient excretory system to tolerate and eliminate the excess of $\mathrm{Cu}$ (BRYAN and HUMMERSTON, 1971; GRANT $\boldsymbol{e t}$ al., 1989)

Polimesoda carolineana concentrates 0.91 times more $\mathrm{Cr}$ than Rangia cuneata and Rangia flexuosa. Polimesoda carolineana bioconcentrates 0.24 times more $\mathrm{Cr}$ than $\mathrm{Cu}$ in the sediments (Tables 14 and 16). This is associated to the total $\mathrm{Cr}$ concentration values in the sediments at Astillero station that is proportional to the $\mathrm{Cr}$ bioconcentration in organisms (BRYAN and LANGSTON, 1992).

In summary only the Astillero station was evaluated for heavy metal concentration in benthic fauna due to the depletion of organisms in the rest of the stations of the Coatzacoalcos River. 
Table 14. Total Cr y Cu concentration and bioavailability values in sediments, water and benthic fauna (january1997

\begin{tabular}{|l|c|c|c|c|c|}
\hline & Total Sediment & Bioavailable & Water & Polimesoda $\mathbf{m g} / \mathbf{l}$ & Rangia \\
\hline $\mathbf{C u}$ & 13.7 & 5.99 & 7.0 & 9.89 & 10.92 \\
\hline $\mathbf{C r}$ & 57.3 & 3.32 & 3.24 & 9.89 & 10.92 \\
\hline
\end{tabular}

Total sediment $=\mathrm{mg} / \mathrm{l} ;$ Bioavailable $=\mathrm{mg} / \mathrm{l} ;$ Water $=\mu \mathrm{g} / \mathrm{l} ;$ Polimesoda carolinean $a=\mathrm{mg} / \mathrm{Kg} ;$ Rangia cuneata y $R$. flexuosa $=\mathrm{mg} / \mathrm{Kg}$

Table 15. Ratio of $\mathrm{Cu}$ and $\mathrm{Cr}$ concentration values in benthic fauna and water

\begin{tabular}{|l|c|c|}
\hline \multicolumn{3}{|c|}{ Benthic fauna / water } \\
\hline & Polimesoda & Rangia \\
\hline $\mathbf{C u}$ & 1410 & 1560 \\
\hline $\mathbf{C r}$ & 3050 & 3370 \\
\hline
\end{tabular}

Table 16. Ratio of $\mathrm{Cu}$ and $\mathrm{Cr}$ concentration values in benthic fauna and sediments

\begin{tabular}{|l|c|c|}
\hline \multicolumn{3}{|c|}{ Benthic fauna / sediment } \\
\hline & Polimesoda & Rangia \\
\hline $\mathbf{C u}$ & 0.72 & 0.80 \\
\hline $\mathbf{C r}$ & 0.175 & 0.19 \\
\hline
\end{tabular}

Factor analysis for the impacted stations.

A varimax rotated factor analysis (FA) was carried out to find the coefficients and proportions of six variables $\left(\mathrm{pH}, \mathrm{T}^{\mathrm{o}}, \mathrm{O}_{2}\right.$, turbidness, $\mathrm{Cu}$ and $\mathrm{Cr}$ ) for the highest impacted stations of the Coatzacoalcos River. A previous Kolmogorov-Smirnov normality test for the six variables entered in the FA was carried out (Table 17) due to the fact that multivariate procedures required data which do not departure markedly from the normal distribution (Swan and Sandilands, 1995). For the FA, the Kaiser criterion was used for factor retention (i.e. eigenvalues > 1.00) (LINDERMAN et al., 1980). The data were arranged in the form of a $\mathrm{N} \times \mathrm{n}$ matrix in which $\mathrm{N}=$ number of stations $(\mathrm{N}=12)$ and $\mathrm{n}=$ number of variables $(\mathrm{n}=6)$. The results showed that $\mathrm{pH}, \mathrm{T}^{\mathrm{o}}, \mathrm{O}_{2}$ and turbidness were the highest variable loads in the first component (Table 18). The first component accounted for the $57.84 \%$ of the total variance. The second component, account for the $27.81 \%$ of the total variance, with $\mathrm{Cu}$ and $\mathrm{Cr}$ as highest variable loads (Table 18).

The Kolmogorov-Smirnov test for normality shows that the null hypothesis of normality is accepted at the $\rho=0.05$ level of significance (Table 17). This implies that the variables entered in the FA followed a normal distribution.

Furthermore, the FA suggests that the highest impacted stations of the Coatzacoalcos River are influenced by the lack of turbidness and depletion of $\mathrm{O}_{2}$ with high temperatures related to industrial discharges (MÉNDEZ, 1998). Also, a high $\mathrm{Cu}$ and $\mathrm{Cr}$ concentrations seems to play a role in the impact that the river shows when water and sediments are analyzed. Hence, the FA supports the previous analyzed data results which suggest that little turbidness, depletion of $\mathrm{O}_{2}$, high temperatures and high $\mathrm{Cu}$ and $\mathrm{Cr}$ concentration in water and sediments 
are parameters which are contributing to the environmental impact of the Coatzacoalcos River.

Table 17. Kolmogorov-Smirnov test summary

\begin{tabular}{|l|l|l|l|r|r|l|}
\hline Variables & $\mathbf{N}$ & $\mathbf{D}$ & $\mathbf{D}^{\prime}$ & \multicolumn{1}{|c|}{ mean } & variance & $\rho$ \\
\hline $\mathbf{p H}$ & 12 & 0.13 & 0.37 & 7.9 & 0.28 & 0.05 \\
\hline $\mathbf{T}^{\mathbf{0}}$ & 12 & 0.12 & 0.37 & 24.8 & 4.43 & 0.05 \\
\hline $\mathbf{O}_{\mathbf{2}}$ & 12 & 0.18 & 0.37 & 2.6 & 6.04 & 0.05 \\
\hline Turbidness & 12 & 0.15 & 0.37 & 7.8 & 45.65 & 0.05 \\
\hline $\mathbf{C u}$ & 12 & 0.26 & 0.37 & 5.4 & 32.65 & 0.05 \\
\hline $\mathbf{C r}$ & 12 & 0.09 & 0.37 & 4.4 & 5.43 & 0.05 \\
\hline
\end{tabular}

$\mathrm{N}=$ number of observations; $\mathrm{D}=$ Kolmogorov-Smirnov computed value; $\mathrm{D}^{\prime}=$ Kolmogorov-Smirnov critical value; $\rho=$ level of significance

Table 18. Factor analysis summary

\begin{tabular}{|l|c|c|}
\hline \multicolumn{1}{|c|}{ Variables } & Factor 1 & Factor 2 \\
\hline $\mathbf{p H}$ & -0.87 & 0.28 \\
\hline $\mathbf{T}^{\mathbf{0}}$ & 0.96 & -0.06 \\
\hline $\mathbf{O}_{\mathbf{2}}$ & 0.87 & 0.21 \\
\hline Turbidness & 0.84 & -0.35 \\
\hline $\mathbf{C u}$ & 0.25 & -0.87 \\
\hline $\mathbf{C r}$ & 0.05 & -0.94 \\
\hline Total variance & $57.89 \%$ & $27.81 \%$ \\
\hline eigenvalues & 3.47 & 1.90 \\
\hline
\end{tabular}

\section{CONCLUSIONS}

1. - The first and fourth samplings showed that most of the sediments in the Coatzacoalcos River are transported by suspension during the rainy season. In contrast saltation is the main mode of sediment transport during the dry season (second and third sampling).

2.- The stations with higher environmental impact due to industrial and urban discharges in the river were Teapa, Darsena Adentro, Astillero, San Antonio, Terranova, Sta. Alejandrina, Uxpanapa, Boca and Nanchital. Higher $\mathrm{Cu}$ and $\mathrm{Cr}$ concentration values in sediments and water were observed in these stations. The Astillero station was the only site with efficient recovery of benthic fauna with high heavy mineral concentration. Depletion of organisms is due to the intensive dredging activity in the past decades and low $\mathrm{O}_{2}$ values in the water column of the majority of the stations in the Coatzacoalcos River.

3. - Organisms like Rangia concentrate 1.1 times more $\mathrm{Cu}$ than $\mathrm{Cr}$ than Polimesoda in sediments. Polimesoda carolineana, Rangia cuneata and Rangia flexuosa concentrate 2.2 times more $\mathrm{Cr}$ than $\mathrm{Cu}$ in water. Rangia also concentrates 4.2 times more $\mathrm{Cu}$ than $\mathrm{Cr}$ in sediments. This probably indicates that the three species have an efficient excretory system to tolerate and eliminate the excess of $\mathrm{Cu}$.

4. - Organisms like Polimesoda carolineana concentrate 0.91 times more $\mathrm{Cr}$ than Rangia cuneata and Rangia flexuosa. Polimesoda carolineana bioconcentrates 0.24 times more $\mathrm{Cr}$ than $\mathrm{Cu}$ in the sediments. This is associated to the total $\mathrm{Cr}$ concentration values in the sediments at Astillero station that is proportional to the $\mathrm{Cr}$ bioconcentration in organisms. 
5. - A varimax rotated factor analysis suggests that the highest impacted stations of the Coatzacoalcos River are influenced by the lack of turbidness and depletion of $\mathrm{O}_{2}$ with high temperatures related to industrial discharges and high $\mathrm{Cu}$ and $\mathrm{Cr}$ values in sediments and water.

\section{ACKNOWLEDGMENTS}

We thank to Eduardo Morales de la Garza and Susana Santiago Pérez for his invaluable help in the laboratory. This research was financed by, Instituto Mexicano del Petróleo Project FIES 95-122-VI. The first author benefited from a scholarship from CONACyT, IMP and Fundación Telmex.

\section{REFERENCES}

ALVAREZ-RIVERA, U., L. ROSALES-HOZ y A. CARRANZA-EDWARDS. Heavy metals in Blanco River sediments, Veracruz, México. An. Inst. Cienc. del Mar y Limnol., Univ. Nal. Autón. México, 13(2): 1-10. 1986.

APHA, AWWA, WEF. Standard Methods for Examination of Water and Wastewater, 19th edition, Washington for America Public Health Association. U.S.A. pp. 1234. 1995.

BAHENA, J. Evaluación espacial y temporal de metales pesados en sedimentos de la parte baja del Río Coatzacoalcos. México. Tesis de maestría, Instituto de Ingeniería, UNAM. México. 1999.

BOtello, V. A., y PÁEZ-OSUNA, F. El Problema Crucial; La Contaminación. In Serie Medio Ambiente en Coatzacoalcos. Vol. 1, México. CECODES - Universidad Veracruzana. pp.180. 1986.

BOTELlo, V. A.; ROJAS, G. J.; BENÍTEZ, J. A. y ZÁRATE L. D. (Eds.) Golfo de México Contaminación e Impacto Ambiental: Diagnóstico y Tendencias. EPOMEX Serie Científica 5, Universidad Autónoma de Campeche. 666 p. 1996.

BRYAN, G. W. and HUMMERSTONE, L. G. Adaptation of the polychaete Nereis diversicolor to estuarine sediments containing high concentrations of heavy metals.1. General observations and adaptation to copper. J. Mar. Biol. Asoc. UK. 845-63. 1971.

BRYAN, G. W. AND LANGSTON, W. J. Bioavailability, accumulation and effects of heavy metals in sediments with special reference to United Kingdom estuaries. Environmental Pollution. 1992.

CEM. Microwave Digestion Applications Manual. CEM Corporation. 1994. 
CHAPMAN, D. Y KIMSTACH, V. The Selection of Water Quality Variables, In: Water Quality Assessments, Chapman D. \& Hall Ed., UK. pp. 51-119. 1992.

ESPINA, S. Y C. VANEGAS. Ecotoxicología y contaminación, p. 45-68. In: A. V. BOTELLO, J. L. ROJAS GALAVIZ, J. A. BENÍTEZ y D. ZÁRATE LOMELÍ (Eds.) Golfo de México, Contaminación e Impacto Ambiental: Diagnóstico y Tendencias. EPOMEX Serie Científica 5. Universidad Autónoma de Campeche. México, pp. 5 666. 1996.

FIGUEROA N. A. Determinación del metilmercurio en mojarra prieta (Cichlosoma guttlatum) y en los sedimentos de los ríos Coatzacoalcos y Uxpanapa del Estado de Veracruz. Tesis Facultad de Ciencias Biológicas, U. V. Jalapa, Veracruz pp.49. 1986.

FOLK, R. L. Petrology of Sedimentary Rocks. Hemphill, Austin, Texas, 182 pp. 1974.

FÖRSTNER, U. and WITTMANN, G. T. W. Metal Pollution in the Aquatic Environment. Springer Verlag. Berlin Heidelberg. 1979

GAllegOS, M. Petróleo y Manglar. In Serie Medio Ambiente en Coatzacoalcos. Vol 3, CECODES, Universidad Veracruzana, México pp.102. 1986.

GARCÍA, E. Modificaciones al sistema de clasificación climática de Köeppen (para adaptarlo a las condiciones de la República Mexicana). 3a Ed. Instituto de Geografía, UNAM. México pp. 42. 1988.

GARCÍA, V. Sistema natural (Subsistema Acuático) en Coatzacoalcos Veracruz. Instituto Mexicano del Petróleo. Informe Técnico. 1996.

GONZÁLEZ-MACIAS, M.C., GONZÁLEZ, L.M.C y GARCÍA V.V.M. Efectos de los dragados de mantenimiento en el ambiente costero en Coatzacoalcos, Veracruz. Oceanología 1 (4) pp. 109-117. 1994.

GRANT, A., HATELY, J. G. and JONES, N. V. Mapping the ecological impact of heavy metals on the estuarine polychaete, Nereis diversicolor using inherited metal tolerance. Mar. Pollut. Bull. 235-238. 1989.

GUERRA, F. D. Aspectos generales de la hidrología del Río Coatzacoalcos en la parte baja, en la temporada de 1987-1988. México. Tesis de Licenciatura, ENEP Iztacala, UNAM, 48 pp. 1990.

INEGI. Carta Geológica E15-1-4. Coatzacoalcos, Veracruz, México (Escala 1:250000). Instituto Nacional de Estadística, Geografía e Informática. 1980a

INEGI. Carta topográfica E15-A85. Coatzacoalcos, Veracruz, México (Escala 1:50000). Instituto Nacional de Estadística, Geografía e Informática. 1980 b. 
KONHAUSER, O.K., POWELL, A. M., FYFE, S. W., LONGSTAFFE, J. F. and TRIPARTHY, S. Trace element chemistry of major rivers in Orissa State, India. Environmental Geology 29 (1-2). 132-141 pp. 1997.

KRUMBEIN, W. C and PETTIJOHN, F. J. Manual of sedimentary petrography. The Century Earth Science Series. New York, U.S.A. pp. 549. 1938.

LINDERMAN, R.H., MERENDA, P.F. and GOLD, R. Introduction to bivariate and multivariate methods. New York Scott, Foresman \& Co. 1980.

MÉNDEZ, C. Dinámica química del estuario del Río Coatzacoalcos. Tesis de Maestría. Instituto de Ingeniería, UNAM. México. pp 90. 1997.

NAUEN, A. Impacto ambiental de la industria petrolera en el río Coatzacoalcos, Veracruz, pp. 541-554. In A. V. BOTELLO, J. L. ROJAS GALAVIZ, J. A. BENÍTEZ Y D. ZÁRATE LOMELÍ (Eds.) Golfo de México, Contaminación e Impacto Ambiental: Diagnóstico y Tendencias. EPOMEX Serie Científica 5. Universidad Autónoma de Campeche. México, pp. 666. 1996.

ORTIZ-ZAMORA, G. y CARRANZA-EDWARDS, A. Los sedimentos como receptores potenciales de metales: Estudio de aplicación en el Río Coatzacoalcos. Actas INAGEQ. 3: 245-250 pp. 1997

ORTIZ-ZAMORA, G., HUERTA -DÍAZ, M.A., SALAS-DE-LEÓN D.A. Y MONREALGÓMEZ M.A. Degrees of pyritization in the Gulf of Mexico in sediments influenced by the Coatzacoalcos and the Grijalva-Usumacinta rivers. Ciencias Marinas, 28(4):369-379. 2002.

ROSALES-HOZ, L. y CARRANZA-EDWARDS, A. Heavy Metals in Sediments from Coatzacoalcos River, México. Bull. Environ. Contam. Toxicol. 60:553-561 pp. 1998.

ROSALES-HOZ, L., A. CARRANZA-EDWARDS Y U. ALVAREZ-RIVERA. Sedimentological and Chemical Studies in Sediments from Papaloapan River, Mexico. An. Inst. Cienc. del Mar y Limnol., Univ. Nal. Autón. México, 13(3): 263-272. 1986.

ROSAS, P. L., A. BÁEZ, Y R. BELMONT. Oyster (Crassostrea virginica) as indicator of heavy metals pollution in some lagoons of the Gulf of México. Water, Air and Soil Pollution. 20: 127-135 pp. 1983.

SADIQ, M. Toxic Metal Chemistry in Marine Environments. Marcel Dekker Inc. New York. 390 pp. 1992.

VILLANUEVA, F. S. Y F. PÁEZ-OSUNA,. Niveles de metales en el Golfo de México: agua, sedimentos y organismos. p. 309-347. In : A. V. BOTELLO, J. L. ROJAS GALAVIZ, J. A. BENÍTEZ Y D. ZÁRATE LOMELÍ (Eds.) Golfo de México, Contaminación e Impacto 
Ambiental: Diagnóstico y Tendencias. EPOMEX Serie Científica 5. Universidad Autónoma de Campeche. México, pp. 666. 1996

VISHER, G. Grain size distributions and depositional processes. Jour. Sed. Perro. Vol. 39. No 3: 1074-1106. 1969.

YASUO, Y. Selected Papers on Environmental Hydrology. $29^{\text {th }}$ International Geological Congress (161). Kyoto, Japan 1992. International Association of Hydrogeologists Vol. 4, 1993. 